J. Agric. Res. \& Dev. 13(1)34-45. Copy@ 2014. Faculty of Agriculture, University of Ilorin

\title{
Effect of Periods of Field Establishment and Irrigation on Growth and Yield Performance of Thevetia peruviana (Pers.) Schum
}

\author{
C. M. ABOYEJI, ${ }^{*}, 1$, Y. A. ABAYOMI, ${ }^{1}$ AND M. O ADULOJU ${ }^{2}$ \\ ${ }^{1}$ Agronomy Department, University of Ilorin, Ilorin, Nigeria. \\ ${ }^{2}$ College of Agricultural Sciences, Landmark University, Omu-Aran. Nigeria \\ * Corresponding author- Aboyeji, C.M chrismuyiwa@yahoo.com. \\ http://dx.doi.org/10.4314/jard.v13i1.4
}

\begin{abstract}
Two irrigation regimes on the growth and yield performance of Thevetia peruviana (Pers) Schum were evaluated during the 2010 and 2011 rainy seasons. The study was carried out at the Research Farms of the Bio-fuel and Alternate Renewable Energy Ltd, Edidi, Kwara State in the southern Guinea savannah of Nigeria. Mature seeds were sown in March and May of both years and transplanted in May (early) and July (late) respectively. During each of the field establishments, early and late of the two years, the treatments consisted of two irrigation regimes (irrigated and non irrigated) and one plant population (2,500 plants ha ${ }^{-1}$ ), laid out in Randomised Complete Block Design with four replicates. Application of irrigation significantly increased plant height, number of primary branches, stem girth, number of harvested seeds, weight of harvested seeds, seed length, seed diameter but delayed number of days to first and 50\% flower appearance at late period of field establishment while the effect of irrigation regimes was not significant on these parameters at early period of field establishment. The plants should therefore be irrigated during the dry season if the field establishment was done late (around July and August) to improve the vegetative growth and yield performance but if transplanting was done early (around May) irrigation may not be necessary. Early field establishment is therefore recommended.
\end{abstract}

Keywords: - Field Establishment, Flowering age, Irrigation, Thevetia peruviana and Yield

\section{INTRODUCTION}

Thevetia peruviana (Pers) Schum. is an evergreen tropical arborescent shrub in the family Apocynaceae of the order Gentianales. It is commonly known as Yellow oleander (nerium), Lucky nut, Be-still tree, gum bush, bush milk, exile tree in India. In spite of the high oil content (67\%) of its kernel (Azam et al., 2005) and favourable protein content (37\%) in de-oil cake (Ibiyemi et al., 2002), it has remained only an ornamental, fencing or wasteland plant. The plant has a milky sap, rich in a compound called "thevetin" that is useful in the treatment of heart related diseases and cure for breast cancer (Bose et al., 1999), but extremely poisonous in its natural form, as are all the parts of the plant. The seeds when pressed to obtain a semi-drying bio-oil (50-67\%) is good for the production of bio-diesel and its oleic acid (55\%) is close to the value computed for an ideal biodiesel $(70 \%)$.

Water is the major factor limiting crop production in many regions of the world. All physiological processes like photosynthesis, cell turgidity, growth of cells and tissues in plant are directly or indirectly affected by water (Reddi and Reddi 1995). Increase in seed yield of Indian mustard (Brassica juncea) with increase in number of irrigations 


\section{M. ABOYEJI, et al}

has been reported by Hati et al. (2001). Application of irrigation can increase the seed yield of canola (Brassica napus canola) from 41.7 to $62.9 \%$ (Panda et al., 2004).

Shehata (1992) working on cypress (Cupressus sempervirens) and river red gum (Eucalyptus camaldulensis), El-Tantawy et al. (1993) on river red gum (Eucalyptus camaldulensis), Azza et al. (2006) on chinaberry (Melia azedarach) seedlings and Azza et al. (2006) on swamp cypress (Taxodium distichum), supplied seedlings with three soil moisture contents (40, 60 and $80 \%$ of water holding capacity). They observed that plant height, stem diameter, fresh and dry weight of leaves, stem and roots were increased by increasing soil moisture but root length and fresh and dry weight of roots were decreased. Also, Uday et al. (2001) studied the effect of irrigation (at field capacity $10.4 \%$ w/w) 0.2 F.C., 0.5 F.C. and 10 F.C. levels) on growth of jojoba (Simmondsia chinensis) and found that growth was increased with increasing irrigation levels.

Neil et al. (2006) observed that increase in tree girth and yield caused by irrigation and bare soil, particularly in dry years, together with the lack of response to the larger rate of fertilizer application, suggests that water was more of a limiting factor than nitrogen supply for orchards. Haq et al. (1996) found a significant increase of yield where crop was watered properly as compared to where crop faced water stress. Clinton et al. (2004) also showed that the maximum yield requires a uniform moisture distribution and maintaining high and non fluctuated soil moisture within the root zone.

Metwally et al. (2002) in their study on roselle (Hibiscus sabdarifa), and Azza et al. (2007) on bauhinia (Bauhinia variegate) seedlings, found that plant height, stem diameter and fresh and dry weight of leaves, stem and root decreased with prolonged watering intervals. Water is a major constituent of tissue, a reagent in chemical reaction, a solvent for and mode of translocation for metabolites and minerals within plant and is essential for cell enlargement through increasing turgor pressure. With the occurrence of water deficits/stress many of the physiological processes associated with growth are affected and under severe deficits, death of plants may result. The response of a crop to water stress varies with crop species, crop growth stage, soil type, environment and season. Water stress also affects crop phenology, leaf area development, flowering, pod setting and finally results in low yield. Water stress reduced plant growth and yield regardless of whether the stress was imposed when the plants were in the vegetative or reproductive stage of development (Thomas et al., 2004). Plant water stress, often times caused by drought, can have major impacts on plant growth and development. Plant water stress can be the cause of lower yields and possible crop failure. The effects of plant water stress vary between plant species. Early recognition of water stress symptoms can be critical to maintaining the growth of a crop. The most common symptom of plant water stress is wilting. The severity of the water stress response varied with cultivar and plant density (Fatima et al., 2000). However, water stress during the reproductive stage affected grain yield more severely.

The beneficial effects of water stress have been reported by many researchers who worked on the effect of deficit irrigation of fruit flowering, fruit maturity and fruit ripening. Berenguer et al. (2002) observed that flower initiation and maturity of olive fruit (Olea europaea) was accelerated with dryness. Marsal et al. (2004) found that the maturation of late-maturing peach (Prunus persica) was advanced by one week when 


\section{Growth and Yield Performance of Thevetia peruviana}

using the regulated deficit irrigation technique. In a similar study, Mpelesaka et al. (2001) observed advanced fruit maturity with the application of late deficit irrigation and whole season deficit.

The objective of the study was to evaluate the effect of two irrigation regimes at different periods of field establishments on the growth and yield performance of Thevetia peruviana.

\section{MATERIALS AND METHODS}

The trials were conducted during the 2010 and 2011 rainy seasons at the Research Farm of the Biofuels and Alternate Renewable Energy Ltd, Edidi, Kwara State, Southern Guinea Savanna of Nigeria. Rainfall started in March and ended in October or early November with a break of about two weeks either in July or August. Edidi, Kwara State has an average annual rainfall of between $1000 \mathrm{~mm}-1400 \mathrm{~mm}$ which is peculiar to the southern Guinea savanna areas. On the average there are about $6-7$ rainy days per month, usually between May and October. The total annual rainfall in 2011 was higher than that of 2010, even though the monthly rainfall distributions for the two years were similar. The dry season started from November and ended by February/March of the following year.

\section{Experimental Design:}

In each of the field establishments i.e early and late of the two years, the treatments consisted of two irrigation regimes (irrigated and non irrigated) and one plant population (2,500 plants ha $\left.{ }^{-1}\right)$, laid out in Randomised Complete Block Design with four replicates.

\section{Land Preparation and Planting:}

The land was ploughed once and harrowed twice to pulverized the soil. Thereafter the field layout was carried out to mark out the appropriate number of treatment plots. The size of each plot in the experiment was $10.0 \mathrm{~m} \times 8.0 \mathrm{~m}=80 \mathrm{~m}^{2}$ (20plants/plot at $2.0 \mathrm{~m}$ by $2.0 \mathrm{~m}$ spacing) and there were two (2) plots in each replicate. Thevetia seeds were collected from the wild and pre-germinated in a covered and protected nursery in plastic bags for 8 weeks before they were transplanted on a flat field at a spacing of $2 \mathrm{~m}$ by 2 meters.

\section{Irrigation:}

In each of the four replicates, the alternate plots were irrigated deeply (for one hour on each application) twice every week with the aid of overhead sprinklers (rotary sprinkler head) during the dry season while the other plots were left un-irrigated. In other to prevent seepage of water from irrigated treatments to non irrigated treatments, ridges were made across each irrigated treatments. Irrigation exercise lasted for three months for both the early and late period of field establishments during the 2010 and 2011 experimental trials.

\section{Weed Control:}

Glyphosate a systemic and non-selective herbicide was used at the rate of $2.5 \mathrm{~kg}$ a.i ha ${ }^{-1}$ using Knapsack sprayer to control both annual and perennial weeds at intervals of 8 weeks. The herbicide was carefully applied so that it does not contact with any green part of the tree, including the trunk. 


\section{Data Collection:}

The following parameters were evaluated in the two seasons: -

i. Plant height at 20, 24, 28 and 32 weeks after transplanting (WAT)

ii. Number of primary branches at 20, 24, 28 and 32 weeks after transplanting (WAT)

iii. Stem girth 20, 24, 28 and 32 weeks after transplanting (WAT)

iv. Number of days to first and $50 \%$ flower appearance

v. Number of days from planting and from flowering to fruit maturity

vi. Number and weight of harvested seeds

vii. Seed length and diameter

viii. Dry weight of 10 seeds

\section{Data Analysis:}

The data collected was subjected to statistical analysis of variance (ANOVA) using Statistical Analysis Software (SAS) and the significant treatment means were compared using the Least Significant Difference (LSD) at 0.05 level of probability $(\mathrm{p} \leq 0.05)$.

\section{RESULTS}

Plant height: The height of Thevetia peruviana plant as influenced by irrigation regimes at both the late and early field establishments is presented on Table 1. Irrigating late field established plants significantly increased the plant height when compared with non irrigated plants while the difference between the two irrigation regimes when the field establishment was done early was not significant.

Number of primary branches: The effects of irrigation regimes and periods of field establishment on number of primary branches are shown on Table 2. The difference in number of primary branches/plant between the two irrigation regimes at 20 WAT on late field established plants and at all weeks after transplanting on early field established plant were not significant but the increase in number of primary branches/plant was significant at 24, 28 and 32 WAT on late field established plants.

Table 1: Mean effect of late and early periods of field establishment and irrigation regimes on plant height $(\mathrm{cm})$ of Thevetia peruviana

\begin{tabular}{|c|c|c|c|c|c|c|c|c|}
\hline \multirow[t]{3}{*}{ Treatments } & \multicolumn{8}{|c|}{ Weeks after transplanting (WAT) } \\
\hline & \multicolumn{4}{|c|}{ Late } & & & \multicolumn{2}{|c|}{ Early } \\
\hline & 20 & 24 & 2832 & & 20 & 24 & 28 & 32 \\
\hline \multicolumn{9}{|c|}{ Irrigation Regimes (IR) } \\
\hline Irrigated & 74.43 & $99.26 \mathrm{a}$ & $120.27 \mathrm{a}$ & $138.71 \mathrm{a}$ & 93.47 & 111.19 & 138.67 & 144.87 \\
\hline Non irrigated & 72.36 & $90.59 b$ & $112.84 b$ & $130.44 b$ & 93.67 & 112.56 & 136.32 & 144.82 \\
\hline LSD $(0.05)$ & N.S & 4.02 & 4.93 & 5.18 & N.S & N.S & N.S & N.S \\
\hline
\end{tabular}

Means in a column under any given treatment followed by the same letter(s) do not differ significantly at 0.05 level of probability using the Least Significant Difference (LSD).
$N . S=$
Not significant, WAT
= Weeks after transplanting 


\section{Growth and Yield Performance of Thevetia peruviana}

Table 2: Mean effect of late and early periods of field establishments and irrigation regimes on the number of primary branches (number per tree) of Thevetia peruviana

\begin{tabular}{lrrrrrrrr}
\hline Treatments & \multicolumn{9}{c}{ Weeks after transplanting (WAT) } & \multicolumn{2}{c}{ Early } \\
& $\mathbf{2 0}$ & $\mathbf{2 4}$ & $\mathbf{2 8}$ & $\mathbf{3 2}$ & $\mathbf{2 0}$ & $\mathbf{2 4}$ & $\mathbf{2 8}$ & $\mathbf{3 2}$ \\
\hline \multicolumn{1}{l}{ Irrigation Regimes (IR) } & & & & & & & & \\
Irrigated & 16.30 & 25.14 & $32.80 \mathrm{a}$ & $37.11 \mathrm{a}$ & 21.00 & 27.09 & 34.70 & 41.94 \\
Non irrigated & 16.39 & 25.04 & $28.90 \mathrm{~b}$ & $34.56 \mathrm{~b}$ & 21.24 & 26.98 & 33.47 & 40.50 \\
LSD (0.05) & N.S & N.S & 1.74 & 2.00 & N.S & N.S & N.S & N.S \\
\hline
\end{tabular}

Means in a column of any given treatment followed by the same letter(s) do not differ significantly at 0.05 level of probability using the Least Significant Difference $(L S D) N . S=\quad$ Not significant, WAT = Weeks after transplanting

Stem girth: Table 3 showed the responses of Thevetia peruviana in terms of the stem girth to irrigation regimes and periods of field establishment. Irrigating the plants during the dry season on late field established plants significantly increased the stem girth as compared with plants not irrigated, while on early field established plants, the difference in the stem girth was not significant between the two irrigation regimes.

Table 3: Mean effect of late and early periods of field establishment and irrigation regimes on stem girth of Thevetia peruviana

\begin{tabular}{lccccccccc}
\hline Treatments & \multicolumn{9}{c}{ Weeks after transplanting (WAT) } \\
& $\mathbf{2 0}$ & $\mathbf{2 4}$ & $\mathbf{2 8}$ & $\mathbf{3 2}$ & $\mathbf{2 0}$ & $\mathbf{2 4}$ & $\mathbf{2 8}$ & $\mathbf{3 2}$ \\
\hline Irrigation Regimes (IR) & & & & & & & & \\
Irrigated & $1.07 \mathrm{~b}$ & $1.77 \mathrm{~b}$ & $2.72 \mathrm{a}$ & $3.07 \mathrm{a}$ & 1.99 & 2.40 & 2.95 & 3.57 \\
Non irrigated & $1.34 \mathrm{a}$ & $1.85 \mathrm{a}$ & $2.06 \mathrm{~b}$ & $2.75 \mathrm{~b}$ & 2.04 & 2.46 & 2.99 & 3.35 \\
LSD (0.05) & 0.04 & 0.08 & 0.12 & 0.22 & N.S & N.S & N.S & N.S \\
\hline
\end{tabular}

Means in a column under any given treatment followed by the same letter(s) do not differ significantly at 0.05 level of probability using the Least Significant Difference (LSD)

$$
N . S=\text { Not significant, WAT }=\text { Weeks after transplanting }
$$

Number of days to first and 50\% flower appearance: Table 4 showed the effects of periods of field establishment and irrigation regimes on number of days to the first and 50\% flower appearance. Irrigating the plants resulted in delayed number of days to both first and 50\% flower appearance which was not significant on number of days to first flower appearance at late field establishment.

Number of days from planting and from flowering to fruit maturity: The response of the shrub in terms of number of days from planting and from flowering to fruit maturity under two irrigation regimes and periods of field establishment is presented on Table 5. The effect of irrigation regimes resulted in a non significant increase on the 
number of days to fruit maturity from planting and from flowering at both periods of field establishment.

Number and weight of harvested seeds: Table 6 shows the effects of periods of field establishment and irrigation regimes on the number and weight of harvested seed. At late field establishment, irrigating the plants resulted in a significant increase in the number and weight of seeds harvested, while a non-significant increase was observed in the number and weight of harvested seeds at early field establishment.

Table 4: Mean effect of periods of field establishments and irrigation regimes on number of days to first and $50 \%$ flower appearance of Thevetia peruviana

\begin{tabular}{|c|c|c|c|c|}
\hline \multirow{2}{*}{$\begin{array}{l}\text { Treatments } \\
\text { Late (July) }\end{array}$} & \multicolumn{2}{|c|}{ Days to First Flower Appearance } & \multicolumn{2}{|c|}{ Days to $50 \%$ Flower Appearance } \\
\hline & Early (May) & Late (July) & Early (May) & \\
\hline \multicolumn{5}{|c|}{ Irrigation Regimes (IR) } \\
\hline Irrigated & 242 & $286 b$ & $281 b$ & $295 b$ \\
\hline Non irrigated & 239 & $283 a$ & $266 \mathrm{a}$ & $289 a$ \\
\hline LSD $(0.05)$ & N.S & 2.49 & 11.05 & 2.10 \\
\hline
\end{tabular}

Means in a column under any given treatment followed by the same letter(s) do not differ significantly at 0.05 level of probability using the Least Significant Difference (LSD) N.S = Not significant

Table 5: Mean effect of period of field establishments and irrigation regimes on Number of days from planting and from flowering to fruit maturity of Thevetia peruviana

\begin{tabular}{lcclc}
\hline $\begin{array}{l}\text { Treatment } \\
\text { Late (July) }\end{array}$ & \multicolumn{2}{c}{ Days From Planting } & Days from flowering \\
\hline Irrigation Regimes (IR) & Late (July) & Early (May) & & \\
\hline Irrigated & 321 & 373 & 82 & 88 \\
Non irrigated & 316 & 371 & 81 & 86 \\
LSD (0.05) & N.S & N.S & N.S & N.S \\
\hline
\end{tabular}

Means in a column under any given treatment followed by the same letter(s) do not differ significantly at 0.05 level of probability using the Least Significant Difference $(L S D)$ N.S = Not significant 


\section{Growth and Yield Performance of Thevetia peruviana}

Table 6: Mean effect of periods of field establishment and irrigation regimes on Number and weight of harvested seeds

\begin{tabular}{|c|c|c|c|c|c|c|}
\hline Treatments & & Number of $\mathrm{Ha}$ & rvested Seeds & Weight of Har & rvested Seed & \\
\hline & & Late (July) & Early (May) & Late (July) & Early (May) & \\
\hline Irrigation & gimes (I & & & & & \\
\hline Irrigated & & 6,889a & $\begin{array}{l}8,278 \\
1235 \mathrm{~h}\end{array}$ & $\begin{array}{c}24.42 \mathrm{a} \\
28.05\end{array}$ & 29.57 & Non irrigate \\
\hline LSD (0.05) & ( & $\begin{array}{c}1,611 \\
1788\end{array}$ & N.S & 6.95 & N.S & \\
\hline
\end{tabular}

Means in a column under any given treatment followed by the same letter(s) do not differ significantly at 0.05 level of probability using the Least Significant Difference $(L S D) . N . S=$ Not significant

Seed length, Seed diameter and Dry weight of 10 seeds: The seed length, diameter and dry weight of 10 seeds of T. peruviana as influenced by periods of field establishment and irrigation regimes is shown on Table 7. Irrigation during the dry season did not significantly affect the seed length, seed diameter and dry weight of 10 seeds at early field establishment. However, at late field establishment, irrigation significantly increased all the parameters.

Table 7: Mean effect of periods of field establishments and irrigation regimes on Seed Length, diameter (cm) and dry weight of 10 seeds of Thevetia peruviana

\begin{tabular}{|c|c|c|c|c|c|c|}
\hline \multirow[t]{2}{*}{ Treatments } & \multicolumn{2}{|c|}{ Seed Length } & \multicolumn{2}{|c|}{ Seed Diameter } & \multicolumn{2}{|c|}{ Dry Weight of 10 Seeds } \\
\hline & Late & Early & Late & Early & Late & Early \\
\hline \multicolumn{7}{|c|}{ Irrigation Regimes (IR) } \\
\hline Irrigated & $3.34 \mathrm{a}$ & 2.84 & $1.64 \mathrm{a}$ & 1.48 & $12.75 \mathrm{a}$ & 9.86 \\
\hline Non irrigated & $3.24 \mathrm{~b}$ & 2.81 & $1.59 \mathrm{~b}$ & 1.48 & $11.06 \mathrm{~b}$ & 9.60 \\
\hline $\operatorname{LSD}(0.05)$ & 0.10 & N.S & 0.04 & N.S & 0.86 & N.S \\
\hline
\end{tabular}

Means in a column under any given treatment followed by the same letter(s) do not differ significantly at 0.05 level of probability using the Least Significant Difference (LSD). N.S = Not significant

\section{DISCUSSION}

Water is the major factor limiting crop production in many regions of the world. All physiological processes like photosynthesis, cell turgidity, growth of cells and tissues in plants are directly or indirectly affected by water (Reddi \& Reddi, 1995). Dehghanisanij et al. (2007) reported that vegetative growth significantly increased as the irrigation water applied in different stone fruit trees (cherries, apricots, plums and nactarines) increased.

Irrigating T. peruviana plants resulted in significant increase in the plant height, number of primary branches and stem girth. The significant increase in plant height, number of 


\section{M. ABOYEJI, et al}

primary branches/plant and stem girth were due to more availability of moisture which resulted into increased physiological processes like photosynthesis, cell turgidity, growth of cell and tissues and increased nutrients uptake with irrigation frequencies. These results agree with the earlier reports of Uday et al. (2001) who found that growth was increased with increasing irrigation levels in jojoba (Simmondsia chinensis). It has been reported that for the measurements of wood growth, either the trunk or main branches may be used to compare the responses of trees to different irrigation treatments at the same location (Wiegand and Swanson, 1982).

Plant water stress, often times caused by drought can have major impacts on plant growth and development. When it comes to crops, plant water stress can be the cause of lower yields and possible crop failure. The effects of plant water stress vary between plant species. Early recognition of water stress symptoms can be critical to maintaining the growth of a crop. The most common symptom of plant water stress is plant wilting. As the plant undergoes water stress, the water pressure inside the leaves decreases and the plant wilts drying to a condition of wilt which will reduce growth on nearly any plant (Batten et al., 1994). The significant reduction in plant height, number of primary branches and stem girth when the plants were not irrigated could be as a result of physiological disorders experienced by the plants during the dry season which resulted in reduced rate of photosynthesis and transpiration and consequently reduced growth. Similar results were obtained by Sarker et al. (2005), who reported that water deficit in plants may lead to physiological disorders, such as a reduction in photosynthesis and transpiration. This result also supported the findings of Thomas et al. (2004) who showed that water stress reduced plant growth and yield regardless of whether the stress was imposed when the plants were in the vegetative or reproductive stage of development. In the tropics, however, night temperatures remain too high for flower induction and a dry period is proposed as the environmental cue for flower induction ( $\mathrm{Lu}$ and Chacko, 2000). Number of days to first flower appearance, number of days to $50 \%$ flower appearance, number of days from planting to fruit maturity and number of days from flowering to fruit maturity were found to increase when the plants were irrigated. The result indicated that irrigating the plants delayed number of days to first and 50\% flower appearance, number of days to fruit maturity from planting and number of days to fruit maturity from flowering. This is in line with the findings of Alegre et al. (1999) who found that acceleration in the olive fruit's development to maturity occurs when the water supply was limited. Similar result was also reported by Tovar et al. (2002) who found that, in irrigated olive trees, fruit slowed down the ripening process, and reached the same maturity index later than the fruit of the non irrigated treatment.

The earliness to attain flowering and maturity under no irrigation may be as a result of reduction in the water status of the plants leading to reduction in the activities of the meristematic tissues. Similar report was also given by Berenguer et al. (2002) where they observed that flower initiation and maturity of olive fruit (Olea europaea) was accelerated with dryness (water stress of the tree). Marsal et al. (2004) also found that the maturation of late - maturing peach (Prunus persica) was advanced by one week using the regulated deficit irrigation (RDI) technique. The results of this study also agree with the findings of Mpelesaka et al. (2001) who observed advanced fruit maturity with the application of late deficit irrigation and whole season deficit. In the same regard, Cuevas et al. (2008) concluded in their study that, all deficit irrigation 


\section{Growth and Yield Performance of Thevetia peruviana}

treatments promoted earlier flowering of loquat (Eriobotrya japonica lindl). However, the more severe the water stress was, the earlier the blooming resulted.Water is a major constituent of the tissue, a reagent in chemical reaction, a solvent for and mode of translocation for metabolites and minerals within plant and is essential for cell enlargement through increasing turgor pressure.

The number of fruits and their final size are dependent on the growth of other organs such as the root, shoots, and trunk. Nevertheless, fruit size is considered to be the major fruit characteristic influenced by irrigation (Marsh, 1993). There was an increase in the seed length, seed diameter and dry weight of 10 seeds when the plants were irrigated. This could be as a result of taller plants and higher number of primary branches recorded under irrigation which increased light interception for the process of photosynthesis leading to higher accumulation of photosynthates (assimilates) in the seeds (sink) and consequently, increase in seed length, seed diameter and seed weight. The reductions in the seed length, seed diameter and dry weight of 10 seeds under no irrigation could be attributed to losses of tissue water which inhibits cell division and enlargement. El - Monayeri et al. (1985) reported similar result and showed that the vital roles of water supply at adequate amounts for different physiological processes such as photosynthesis, respiration, transpiration, translocation, enzyme reaction and cells turgidity occurs simultaneously. It could also be attributed to a decrease in the activity of meristematic tissues responsible for elongation, as well as the inhibition of photosynthetic efficiency under insufficient water condition (Siddique et al., 1999).It was also observed that yield increased significantly with the application of irrigation water. The significant increase in yield of $T$. peruviana could be attributed to greater plant height, number of primary branches per plant and the stem girth which translated into more number of flowers per branch and per plant and the subsequent greater yield. Yield increase under irrigation could also be attributed to availability of moisture which facilitated nutrients uptake. Similar result was documented by Haq et al. (1996) who found a significant increase of yield where crop was watered properly as compared to where crop faced water stress.

The reduction in the yield under no irrigation could be as a result of reduced plant height and number of primary branches which in turn reduced the water status of the plant for accumulation of organic solutes. Ali et al. (1999) indicated that soil drying decreased leaf growth thereby reducing leaf water status in addition to accumulation of organic solutes to osmotic adjustment which in turn inhibit the incorporation of small substrate molecules into the polymers needed to grow new cells.

The result also indicated that the period of field establishment affected the plant. Plant height, number of primary branches, stem girth, number of harvested seeds, weight of harvested seeds, seed length, seed diameter and dry weight of 10 seeds were not significant under the two irrigation regimes at early period of field establishment but significant at late period of field establishment. The reason for the non significant of these parameters at early period of field establishment could be attributed to the longer growing period experienced by the early established plants under the two irrigation regimes before the commencement of irrigation during the dry seasons while the significant increase in these parameters at late periods of field establishment may be as a result of physiological disorder experienced by the plants during the dry seasons. 


\section{M. ABOYEJI, et al}

\section{CONCLUSION}

Based on the results of this study, the period of field establishment is very critical and will determine whether or not to irrigate the plants, this is because most of the parameters tested at early period of field establishments were not significant under the two irrigation regimes. Early field establishment is therefore recommended.

\section{REFERENCES}

Alegre, S., Girona, J., Marsal, J., Arbones, A., Mata, M., Montagut, D., Teixido, F., Motilva, M.J., Romero, M.P., 1999. Regulated deficit irrigation in olive trees. Acta Hortic. 474, 373-376.

Ali, M.; C.R. Jonsen; V.O. Mogensen; M.N. Andersen and I.E. Henson. 1999. Root signalling and osmotic adjustment during intermittent soil during sustain grain yield of field grown wheat. Field Crops Research, 62 (1): 35-52.

Azam M.M., Waris A., and Nahar N.M. 2005. Prospects and potential of fatty acid methyl esters of some non-traditional seed oils for use as biodiesel in India. Biomass and Bioenergy, 29, 293-302.

Azza, A.M., Mazher, A.A. Yassen and Sahar, M. Zaghloul. 2007. Influence of foliar application of potassium on growth and chemical composition of Bauhinia variegate seedlings under different irrigation intervals. World. J. Agric. Sci., 3(1): 23-31.

Berenguer, J. M, M. J. Espoda and Gracia, J. L. 2002. Effect of variable water irrigation supply in olive fruit and oil production. Proc. $4^{\text {th }}$. International symposium on olive growing, Acta Horticulturae. 586:341-344

Clinton, C. S.; E. B. G. Feibert; A. B. Pereira and Cedric A. Shock. 2004. Automatic collection, radio transmission, and use of soil water data. Mal information for sustainable agriculture, Malheur Experiment Station.

Cuevas, J., J.J. Hueso and M.C. Rodríguez. 2008. Deficit irrigation as a tool for manipulating flowering date in loquat (eriobotrya Japonica lindl). In: Agricultural Water Management Research Trends Editor: Magnus L. Sorensen, pp. 237-253

Dehghanisanij, H., A. Naseri, H. Anyoji and A.E. Eneji. 2007. Effects of deficit irrigation and fertilizer use on vegetative growth of drip irrigated cherry trees, J. Plant Nutr., 30: 411-425.

El-Monayeri, M.O.; M.Hagazi; H. Ezzat; H.M. Salem and S.M. Tohoun. 1985.Growth and yield of some wheat and barley varieties grown under different moisture stress levels Annals. Agric., Moshtohor, 20: 231-240.

Fatima, S. F., Farooqi, A. H. A. and Srikant, S. (2000). Effect of drought stress and plant density on growth and essential oil metabolism in citronella java (Cymbopogen

winterianus Jowitt) J. Med. Aromatic Plant Sci., 22(IB), 563-567. 


\section{Growth and Yield Performance of Thevetia peruviana}

Hati, K.M., Mandal, K.G., Misra, A.K., Ghosh, P.K., and Acharya, C.L. (2001). Evapo-

transpiration, water-use efficiency, moisture use and yield of Indian mustard

(Brassica juncea) under varying levels of irrigation and nutrient management in

Vertisol . Indian J. Agric. Sci., 74(6): 339-342 .

Haq, I.U., E. Rasul and A. Wahid. 1996. Growth and yield performance of soybean (Glycine max.) under different water regimes. J. Animal and Plant Sci., 6: 63- 65.

Ibiyemi, S.A, V.O Fadipe, O.O Akinremi and S.S Bako. 2002. Variation in oil composition of Thevetia peruviana juss fruits seeds. J Appl. Sci. Environ. Management 6, (2), 61- 65

Lu, P. and Chacko, E.K. 2000. Effect of water stress on mango flowering in low latitude tropics of Northen Australia. Acta Hort. 509, 283-289.

Marsal, J., Areade, T. and Fruticola, U. 2004. Effects of Stage II and Post-harvest Deficit Irrigation on Peach Quality during Maturation and after Cold Storage. J. Sci.Food Agric., 84(6): 561-568.

Marsh, A. W. 1993. Irrigation. "Citrus Industry. Edit. W. Reuter." Univ. Of Califor. div. of Agric. Sci. Vol. 3, p. 230-279.

Metwally, M.Mazrou; M.M.Afify; Hend, E.Wahba; Makarem, A.Mohamed, M.A. Eraki and S. Mahfous 2002. Effect of irrigation and vapor Gard on growth, yield and chemical composition of roselle. Plant Bull National Research Centre, Egypt, 27: 533-548.

Mpelasaka, B. S, M.H Behboudian and Mills, T. M. 2001. Effect of deficit irrigation on fruit maturity and quality of braeburn apple. Science Horticulturae, 90:34. 279- 290

Neil A Hipps, Martin S Ridout, and David Atkinson. 2006. Effects of alley sward width, irrigation and nitrogen fertiliser on growth and yield of Cox's orange pippin apple trees Journal of the Science of Food and Agriculture, Volume 53, Issue 2, pages

159-168, 2006.

Panda, B.B., Bandyopadhyay, S.K. and Shivay, Y.S. (2004). Effect of irrigation level, Sowing Dates and varieties on yield attributes, yield, consumptive water use and water-use efficiency of Indian mustard (Brassica juncea). Indian J. Agric. Sci., 74(6): 339-342

Reddi, G.H.S. and T.Y. Reddi. 1995. Irrigation of principal crops, In: Efficient use of Irrigation water. 2nd ed.: Kalyani Publishers. New Delhi, India, pp. 229-259.

Siddique, M.; R.B. Hamid and M.A. Islam. 1999. Drought stress effect on photosynthetic rate and leaf gas exchange of wheat. Botanical Bull. of Academia Sinica, 40: 141-145. 


\section{M. ABOYEJI, et al}

Thomas, M., J. Robertson, S. Fukai and M.B. Peoples. 2004. The effect of timing and severity of water deficit on growth, development, yield accumulation and nitrogen fixation of mung bean. Field Crops Res., 86: 67-80.

Tovar, M.J., Romero, M.P., Girona, M.J., Motilva, M.J. 2002. 1-Phenylalanine ammonia-lyase activity and concentration of phenolics in developing olive (Olea europaea, L. cv. Arbequina) fruit grown under different irrigation regimes. J. Sci. Food Agric. 82, 892-898.

Uday, B; M.D. Bohra, L.N. Harsh; J.C. Tiwari and U. Burman. 2001. Water relation and growth of Simmondsia chinensis and Prasopis Juliflord seedlings at nursery stage.

Indian Forester, 127: 351-357.

Wiegand, C. L., Swanson, W. A. 1982. Citrus Response to Irrigation. III Tree Trunk and Canopy Growth. J. Rio Grande Walley Hortic. Soc. 35: 97-107. 